\title{
BENJAMIN GOOCH, EIGHTEENTH-CENTURY NORFOLK SURGEON
}

\author{
by
}

\author{
A. BATTY SHAW
}

BeNJAMIN Gooch, a Norfolk surgeon of the eighteenth century, ${ }^{1}$ earned a place for his name in surgical history as the innovator of Gooch's splint ${ }^{2}$ but this was not his only claim to distinction. He was the leading East Anglian surgeon of his day and an outstanding provincial surgeon of the eighteenth century. In 1758 he published the first of three editions of a textbook of surgery and he played a prominent role in the foundation of the first general hospital in Norfolk, the Norfolk and Norwich Hospital. The foundation stone of this hospital was laid in 1771, and the two hundredth anniversary of the event is deemed an appropriate occasion to publish an account of Gooch's life and work.

\section{LIFE AND FAMILY}

Benjamin Gooch's grandfather was a farmer of Wreningham, a village to the southwest of Norwich and his father, the Reverend Benjamin Gooch, was rector of the nearby village of Ashwellthorpe from 1693 until his death in 1728. The Reverend Benjamin Gooch was a scholar of Gonville and Caius College, Cambridge, ${ }^{3}$ and the younger Benjamin was one of three children to survive him. The date of birth of the younger Benjamin Gooch has not been traced but he would have been born in 1707 or 1708 since his tombstone records that he died in February 1776 at the age of sixty-eight years. Of his early education nothing is known but he was apprenticed to a leading Norwich surgeon of the day, David Amyas, of whom he later wrote 'one of the best surgeons I ever knew'. It then appears probable that he studied at the London hospitals and schools; on his return to Norfolk he went as assistant to Robert Bransby of Hapton and later of Shotesham. Gooch succeeded to the practice, married Bransby's daughter, Elizabeth, and from a house in Shotesham that still stands 'practised for more than thirty years in a country situation with a large circle of business, where I was obliged to act in the capacity of a physician as well as surgeon'. But he soon established a reputation for his surgical skill and was called in consultation by his professional colleagues to see surgical cases throughout East Anglia. He was an apothecary-surgeon, both a country general practitioner and a consultant surgeon.

By his marriage to Elizabeth Bransby, Gooch acquired several medical relations. The Bransbys were a family of yeoman farmers who had owned land at Shotesham and in South Norfolk since the sixteenth century; Elizabeth Bransby's second cousin was Maria Susanna Bransby of Shotesham who married the Reverend Samuel Cooper (1740-1800) son of a sucessful Norwich apothecary and brother of William Cooper, a surgeon to Guy's Hospital from 1783-1800. One of their children was 


\section{Benjamin Gooch, Eighteenth-Century Norfolk Surgeon}

Astley Cooper (1768-1841) born at Brooke, three miles from Shotesham who succeeded his uncle as surgeon to Guy's Hospital in 1800.4 Sir Astley Cooper, as he later became, was eight years old when Benjamin Gooch died, so the professional paths of these two related surgeons did not cross. Another medical relative was the Reverend Thomas Havers of Stoke Holy Cross, a village between Shotesham and Norwich; he was both a priest and held a licence from the Bishop of Norwich to practise medicine. Havers married the aunt of Robert Bransby's wife and in his will of 1719 left 'his instruments of surgery to his nephew, Robert Bransby of Hapton Hall, Norfolk'. These instruments included those Havers used for lithotomy-he achieved a great local reputation as a lithotomist-and they would have been available to Benjamin Gooch through Robert Bransby. Gooch's connections by marriage can only have fostered his professional career.

In 1757, when about fifty years of age, Gooch suffered a breakdown in health with 'a heavy affliction'. He went to Bath for its treatment under the care of Jeremiah Pierce, the first surgeon appointed to the Bath Hospital, opened in 1742, and a Fellow of the Royal Society. However, this illness brought Gooch's 'life into imminent danger and obliged me to retire from business ... between two to three years'. On leaving Bath Gooch spent the winter of 1758 in London but did not regain sufficient health to return to general practice at Shotesham. However by 1760 he was in surgical business again' operating in June of that year on 'a reputable tradesman in the City of Norwich [who] had a rotten testicle'. In 1763 he was living in Norwich and he spent the last fifteen years of his life either in Norwich or at Halesworth, where his daughter and son-in-law had settled, but he kept on his house at Shotesham for an article from that address has survived, dated 1 August 1773. In this last period of his life Gooch restricted his professional activities to surgical practice and to the preparation of the second and third editions of his textbook of surgery. Evidence that he never regained his full health is provided in the second edition of his book, published in 1766. Here he states that on account of ill health he 'wrote at intervals when able and at other times employed an amanuensis'; when Mr. T. Fulcher, a country apothecary, wrote asking Gooch to see a case for him in 1769 , his letter asked Gooch to come 'as speedily as the infirm state of your health will allow'.

Benjamin Gooch died at Halesworth, Suffolk 'after a tedious and painful illness' on 11 February 1776 at the age of sixty-eight years. The Norfolk Chronicle of 17 February 1776, in a note of his death described him as 'a benevolent man and a most pious and devout Christian'. His body was brought back to Shotesham where he had been the village doctor for the greater part of his professional life and where his wife's family had lived for two hundred years. Gooch was interred in the churchyard of Shotesham All Saints, beneath the east window; this piece of the churchyard became a family burial place for his widow, his daughter and son-in-law, together with two of his grandchildren, were later buried beside him.

HIS DAUGHTER, LORD THURLOW AND THE ROYAL COLLEGE OF SURGEONS OF ENGLAND

Benjamin and Elizabeth Gooch had one child, Elizabeth, christened on the day she was born, 1 August 1735, at Stratton St. Mary Church, Long Stratton. She was educated at a boarding school and the copy of a letter which her father wrote to 


\section{A. Batty Shaw}

her at school, dated Tasburgh, 11 May 1749, survives. In this letter Gooch gave her advice on 'good Notions and Principles in order to secure you the more effectually against numberless Evils, which People frequently bring upon themselves, thro' inadvertence or want of thought'.

In the village of Shotesham, where Elizabeth Gooch was brought up, the tale is still told that the daughter of their famous village doctor of the eighteenth century became engaged to Lord Thurlow, the Lord Chancellor of England. The marriage ceremony was arranged at the church of Shotesham All Saints, but on the day of the wedding Elizabeth Gooch changed her mind, and the Lord Chancellor returned to the Woolsack a bride-forsaken bachelor. This story has been investigated and found to be true save that the engagement was between Elizabeth Gooch and Edward Thurlow, future Lord Chancellor. At the time of the wedding Thurlow was too young to be Lord Chancellor being under twenty-five years old, and by 1778, the year that he became Lord Chancellor, Elizabeth Gooch was a married woman of fifty-three years and had borne five children. Edward Thurlow's father was an East Anglian parson who lived at Braconash, a village four miles from Shotesham and Edward Thurlow often rode over to visit the Gooch's for the two families were related apart from his engagement to Elizabeth. In later life she gave as her reason for not having married Edward Thurlow that 'she was positively afraid of him'. ${ }^{6}$

Edward Thurlow had a distinguished career at the Bar. He was Solictor-General, Attorney-General and from 1778-92 Lord Chancellor. Charles Fox said of him that 'no man ever was so wise as Thurlow looks' (Fig. 2). Thurlow's biographers make it clear that in spite of a successful legal career, rejection in marriage in his early twenties affected him throughout his life. ${ }^{5,6} \mathrm{He}$ never married though he had a number of children by his mistress. It can only be conjectured, but it may have been the case, that Thurlow's rejection in marriage by a surgeon's daughter, influenced his attitude to a bill to establish a College of Surgeons when it came before the House of Lords in 1797. Lord Thurlow spoke in strong opposition to the bill. This he attacked on a number of grounds but he particularly incensed its surgical sponsors by remarking that 'there is no more science in surgery than in butchery'. Thurlow's speech killed the bill. ${ }^{7,8}$ Among the surgeon's replies to his attack was a pamphlet entitled $A$ dressing for $L^{* *} d T h^{* *} r^{* *} w$ by John Birch, surgeon to St. Thomas's Hospital. ${ }^{9}$ But the surgeons had little cause for concern; their bill to establish a College of Surgeons was submitted to Parliament again in 1798, it was not opposed and passed the Great Seal on 22 March 1800. George III granted permission for the new college to use the prefix 'Royal' and the Royal College of Surgeons of England was thereby founded.

HIS GRANDSON, DURBAN AND DURBANVILLE, SOUTH AFRICA

After her affair with Edward Thurlow, Elizabeth Gooch became engaged to her father's assistant at Shotesham, John D'Urban. Following several years' service as surgeon with the Royal Navy, D'Urban studied in London and Paris before becoming an assistant to Gooch and in 1753 proceeded M.D. at the University of Edinburgh. In the same year, on 8 October, he married Elizabeth Gooch at St. Margaret's Church, Westminster and he must have practised in London for a period since their first child 


\section{Benjamin Gooch, Eighteenth-Century Norfolk Surgeon}

was born there in 1760. On the death of King George II in the same year D'Urban was presented with a royal mourning ring, still in the possession of his descendants, but what position D'Urban held at court is not known. Soon afterwards D'Urban moved to a practice at Halesworth, Suffolk, and later succeeded to his father-in-law's practice at Shotesham. While living at Halesworth the D'Urbans had four further children, the youngest of whom was born on 16 February 1777. This was one year after Benjamin Gooch's death and the child was christened Benjamin after his grandfather. Sir Benjamin D'Urban (1777-1849), as he later became, had a distinguished military and civil career (Fig. 3). He was decorated on several occasions for his services under the Duke of Wellington in the Peninsular War and rose to be Lieutenant-General. He was appointed to several governorships including those of Lieutenant-Governor of the Eastern District of the Cape of Good Hope from 18331837 and Governor and Commander-in-Chief of the Cape of Good Hope from 1842-1847. In 1847 he was appointed Commander of the Forces in British North America where he died in 1849 and was buried in the British Military Cemetery at Montreal. ${ }^{10}$ D'Urban was a popular governor in the Cape of Good Hope and in appreciation of his service there Port Natal was renamed Durban in 1835 and Pampoenskraal in Cape Province that had planned to use the same name, adopted the variant of Durbanville. ${ }^{11}$ Durban, a village in the Eastern Cape, Durban Deep, a mine on the Witwatersrand, Durban Street in Uitenhage and Durban Road in Pietermaritzburg are other places in South Africa named in Sir Benjamin D'Urban's honour.

\section{'CHIRURGICAL WORKS'}

Gooch's work is described for posterity in the pages of his surgical textbook and it was the misfortune of ill health that provided him with the opportunity to write it. It is an outstanding work revealing Gooch's great knowledge of surgery and surgical literature and providing a detailed account of the practice of a country surgeon in eighteenth-century England.

When Gooch was an apprentice the only general surgical books available were by European authors. Samuel Sharp, a former apprentice to Cheselden at St. Thomas's Hospital and himself surgeon to Guy's Hospital from 1733 until ill health forced him to retire in 1757, was the first English surgeon of the century to see the need for a 'treatise of character on that subject [surgery] written in our language'. His famous Treatise on the Operations of Surgery first published in $1739^{13}$ grew steadily in fame and circulation and ran to a tenth edition in 1782. Another general surgical book of the period was a Treatise on Surgery published in 1754 by Joseph Warner, an apprentice to Sharp, who followed him as surgeon to Guy's Hospital for the long period from 1745-1790. Warner's work was written in the same format as that of Gooch's first edition comprising forty-four surgical case histories with commentaries. ${ }^{14}$ But no English work was as comprehensive as $A$ General System of Surgery by Lorenz Heister (1683-1758) of Germany; ${ }^{15}$ its first English edition was published in 1739 and it was the surgical work recommended by William Hunter to his pupils when he opened his School of Anatomy in 1745. Textbooks of general surgery by English authors were few in the mid-eighteenth century and for a surgeon practising from a 


\section{A. Batty Shaw}

small Norfolk village to write one was a remarkable achievement.

In the preface to the one volume of the first edition published in 1758 and entitled Cases and Practical Remarks in Surgery ${ }^{12}$ Gooch disclosed that he wrote the manuscript during his illness at Bath and intended it 'for the information of those under [his] own care'. He would have been referring to the pupils and young surgeons who came to him for training and the work was written to meet the need for 'a plain methodical guide upon the subject', that Gooch had found unavailable when he was an apprentice. Gooch had sent the manuscript to Sir John Pringle and other influential friends in London who gave their opinion that this should be published and not merely be available for his own pupils and young surgeons. He dedicated the volume to William Fellowes, his patron and squire, who had erected a cottage or village hospital at Shotesham, for the needs of the parish sick. 'It was your erecting an Infirmary for the benefit of the poor which gave me an opportunity of making some of the following observations in surgery; and when the opinion of my friends inclined me to publish them a sense of my obligations to you called for this profession of my gratitude.'

The first edition in one volume was well received and in 1766 Gooch published two volumes of a second edition ${ }^{16}$ followed in 1773 by a third volume 'as an Appendix' to them. ${ }^{17}$ The second volume was a revised version of Cases and Practical Remarks in Surgery and the first volume was entitled $A$ Practical Treatise on Wounds and other Chirurgical Subjects to which is prefixed a short Historical Account of the Rise and Progress of Surgery and Anatomy, addressed to Young Surgeons. This volume dealt mainly with wounds and fractures but contained chapters on trepanning, the use of sutures, the treatment of aneurysms and is concluded with chapters on methods of 'opening a dead body' and embalming. The 'Appendix' was published seven years later in 1773 by which time the Norfolk and Norwich Hospital had been opened and Gooch had been appointed its firstconsulting surgeon on 9 October 1771 . He dedicated the volume to the Governors of the Norfolk and Norwich Hospital 'as a testimony of the honour done me in electing me as consulting surgeon' and wrote in a foreword 'A Short Account of the Rise and Progress of the Norfolk and Norwich Hospital'. The third volume on Medical and Chirurgical Observations as an Appendix to a former publication contained accounts of further surgical cases he had encountered, commentaries and case reports on medical cases and a miscellany of correspondence and other material that had arisen from other surgeons reading his previous volumes and in other ways. He recounted cases seen in consultation at Woodbridge, Suffolk and other East Anglian towns and villages as well as those that came to see him in Shotesham and Norwich. Gooch worked on a third edition until his death in 1778 and it was published fourteen years later as The Chirurgical Works of Benjamin Gooch, Surgeon; a New Edition with his last Corrections and Additions; its three volumes have the same subtitles as those published in 1758, 1766 and $1773 .{ }^{18}$

Gooch's work was written in an attractive style and he employed the commendable practice of giving references 'to invite you [young surgeons] to consult those distinguished writers I am indebted to'. These references show his familiarity with classical and surgical literature and his case reports reveal an extremely able and conscientious surgeon. In 1775 he drained an empyema with recovery of the patient, he cites several 


\section{Benjamin Gooch, Eighteenth-Century Norfolk Surgeon}

examples of trepanning the skull for head injuries and he recounts his many experiences of dealing with wounds, amputations, infections and fractures, so common a part of eighteenth-century surgical practice. A notable case was that of a parson who had fractured his skull in a fall from a runaway horse. Eleven days later symptoms and signs of a cerebral abscess developed, Gooch trepanned the skull to let out the pus and the parson recovered and lived for several years afterwards. Gooch also described cases successfully operated upon for strangulated hernia and in his account of 'the extirpation of cancerous breasts' he reveals himself as a member of the radical school of surgery in their treatment. 'The utmost attention should be paid to the eradication of every diseased glandular substance that can possibly be discovered, be it ever so small and not leave any in the axilla; and when the operation shall be thought advisable, even when there is some adhesion of the tumour to the pectoral muscle, it is certainly right to dissect off a considerable portion of that along with it.' Of particular interest are his accounts of bladder stone, for with John Harmer of Norwich, Gooch was the leading Norfolk lithotomist of the first half of the eighteenth century and bladder stone was more common in Norfolk than in any other English county. He described a number of cases treated by median or lateral lithotomy and he was the first, or one of the first, to remove a bladder stone through the vagina. ${ }^{20}$ Gooch trained many Norfolk surgeons in lithotomy and the Norfolk and Norwich Hospital that he helped to found later earned an international reputation for its results in the treatment of bladder stone. The hospital's work on all aspects of bladder stone has been described under the title of 'The Norwich School of Lithotomy' with Benjamin Gooch as its founder. ${ }^{19}$

Gooch's scientific approach to surgery is exemplified by his description of an experimental ligation of the femoral artery of a young spaniel and a study of the collateral circulation which followed. It is referred to in his Chirurgical Works and also in a paper he delivered before the Royal Society on aneurysms of the thigh in $1775 ; 21$ on the same day he read a second paper to the Society on amputations above the knee. ${ }^{22}$ Gooch was also an ingenious designer of 'machines' and appliances and his mechanical genius has been compared with that of a Hugh Owen Thomas. ${ }^{2}$ A number of these are illustrated in his Chirurgical Works where he acknowledges the help which Mr. Page, a watch-maker of Norwich, gave in their construction and design. Gooch designed appliances for the treatment of head injuries, prolapse of the rectum and other conditions, but his most famous was the splint he devised for the treatment of fractures and which he first described in 1758 as follows, 'I contrived the fracture case for the leg many years ago.... I have found it useful in compound as well as simple fractures; it has longitudinally all the stiffness of a deal board of the same thickness, and transversely all the flexibility of paper used upon such occasions, which by use and moisture soon loses its property of stiffness; it is made of deal one eighth of an inch thick, with leather glued to it, and cut through to the leather at the distance of one sixth of an inch with a fine saw or a knife, set to a certain gauge' (Fig. 4). Canvas later took the place of leather in its construction, but Gooch's splint, as it became known, remained in use until the 1920s when plaster of Paris bandages, first introduced in 1852, finally took its place.

In his volume of Medical and Chirurgical Observations Gooch referred to profes- 


\section{A. Batty Shaw}

sional experiences, other than surgical. In 1739 he dealt with an epidemic of what 'the common people call the mumps and which I had never seen nor read any description of' and between 1739-42 he was involved in several outbreaks of 'epidemic fever'. He described the case of an attorney who over a period of several years repeatedly shed all his skin including the nails, producing what Gooch termed a 'cuticular glove' of the nails and skin from the hands. Gooch sent details of the case to Joseph Warner who reported Gooch's letter, with an illustration of the cuticular glove, to the Royal Society in 1769. ${ }^{23}$ This report is cited by Gould and Pyle in their volume on Anomalies and Curiosities of Medicine ${ }^{24}$ as one of the earliest descriptions of the rare condition in which, like a serpent, there is recurrent generalized shedding of the human skin (keratolysis). Joseph Warner was a visitor to Gooch at his Norfolk home and in return for 'a hint' in the treatment of cataracts Warner wrote in his Treatise on Surgery that he was indebted 'to my good friend the late Mr. Gooch of Norfolk, whose abilities in the profession of surgery were so great.'25 Joseph Warner (1717-1801) shared with Sir Caesar Hawkins, William Bromfield and Samuel Sharp, the civil surgical practice of London during the eighteenth century ${ }^{26}$ but Warner was only one of the leading medical men of the day whom Gooch knew or with whom he corresponded. He studied under Tonkyns at the Foundling Hospital and Monro at St. George's Hospital and corresponded with Sir John Pringle, the eccentric Messenger Monsey at Chelsea Hospital and others. An especially notable friendship was with William Hunter to whom he often sent pathological specimens. Gooch described William Hunter as 'the most celebrated professor of anatomy that ever was in London. This gentleman's friendship and indulgence I shall ever remember with pleasure and gratitude'. In his turn it can be claimed for Gooch that he was one of the 'most celebrated' provincial surgeons of eighteenth-century England.

\section{SHOTESHAM INFIRMARY AND THE NORFOLK AND NORWICH HOSPITAL}

In his Chirurgical Works Gooch referred on a number of occasions to the treatment and observation of his surgical cases in Shotesham Infirmary. His debt to William Fellowes for founding this cottage hospital for the people of the village of Shotesham was considerable and this Gooch publicly acknowledged. It seems likely that the presence of a surgeon of Gooch's ability in Shotesham was among the reasons that prompted Fellowes to found the hospital and Gooch may well have persuaded Fellowes of the advantages that would accrue from it. Gooch was also associated with Fellowes in his foundation of a hospital for the people of the whole county of Norfolk. This was the Norfolk and Norwich Hospital, built in the county's capital, seven miles from Shotesham. Gooch was this hospital's first consulting surgeon but never was on its active staff nor operated at the hospital.

William Fellowes (1706-75), the philanthropic squire of Shotesham during Gooch's life-time, came of a family that settled in Worcestershire during the sixteenth century. His wealth was inherited from his father, also William Fellowes (1660-1724), ${ }^{27}$ a Senior Master in Chancery, who inherited a considerable fortune from an uncle and married a wealthy heiress. The younger William Fellowes followed in his father's legal footsteps, became a member of Lincoln's Inn and for a few years was Member of Parliament for Ludlow. But he spent the greater part of his life on the 


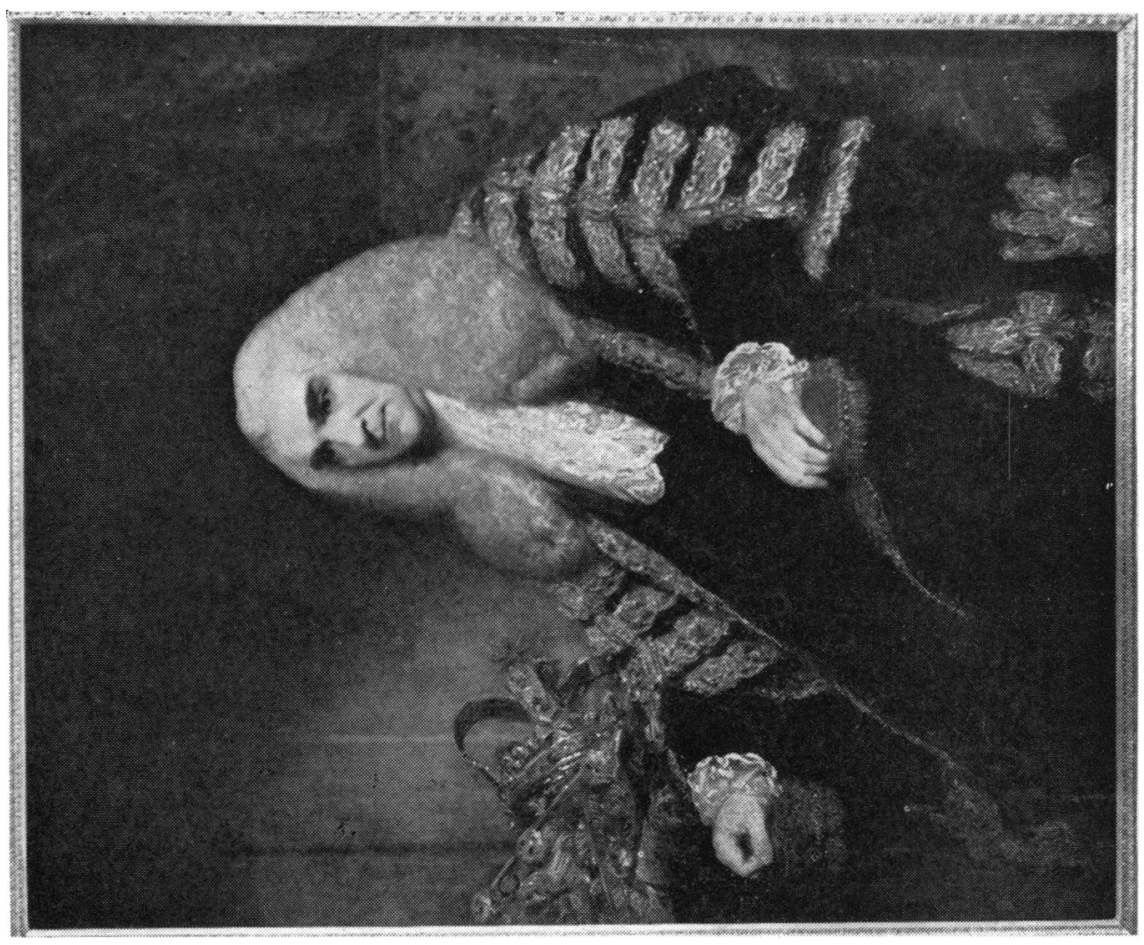

믕

承

$\stackrel{\circ}{\circ}$

흐을

ลิํㅗ

สู่

No

욘.

온 응 웅

ब

苋

造

잉

호 도

है

을

ह

몸

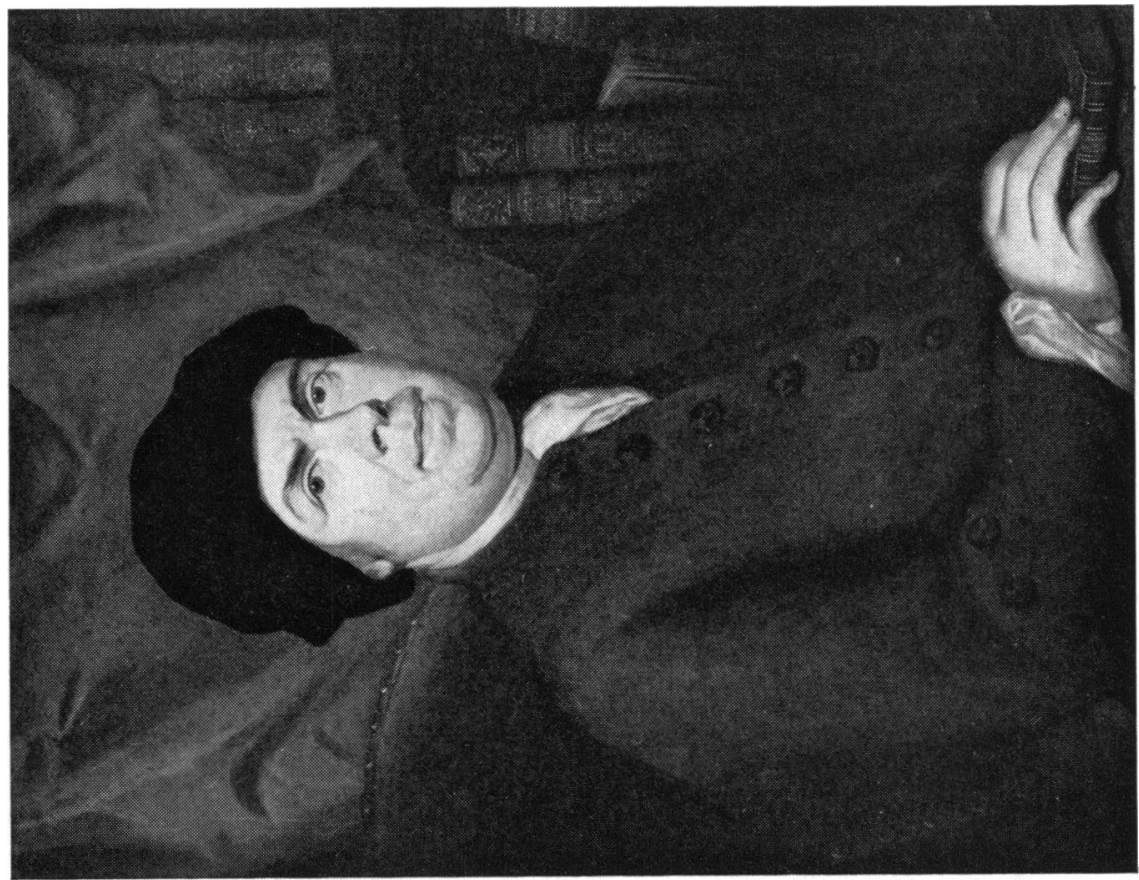

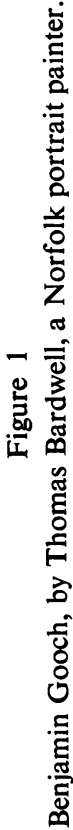



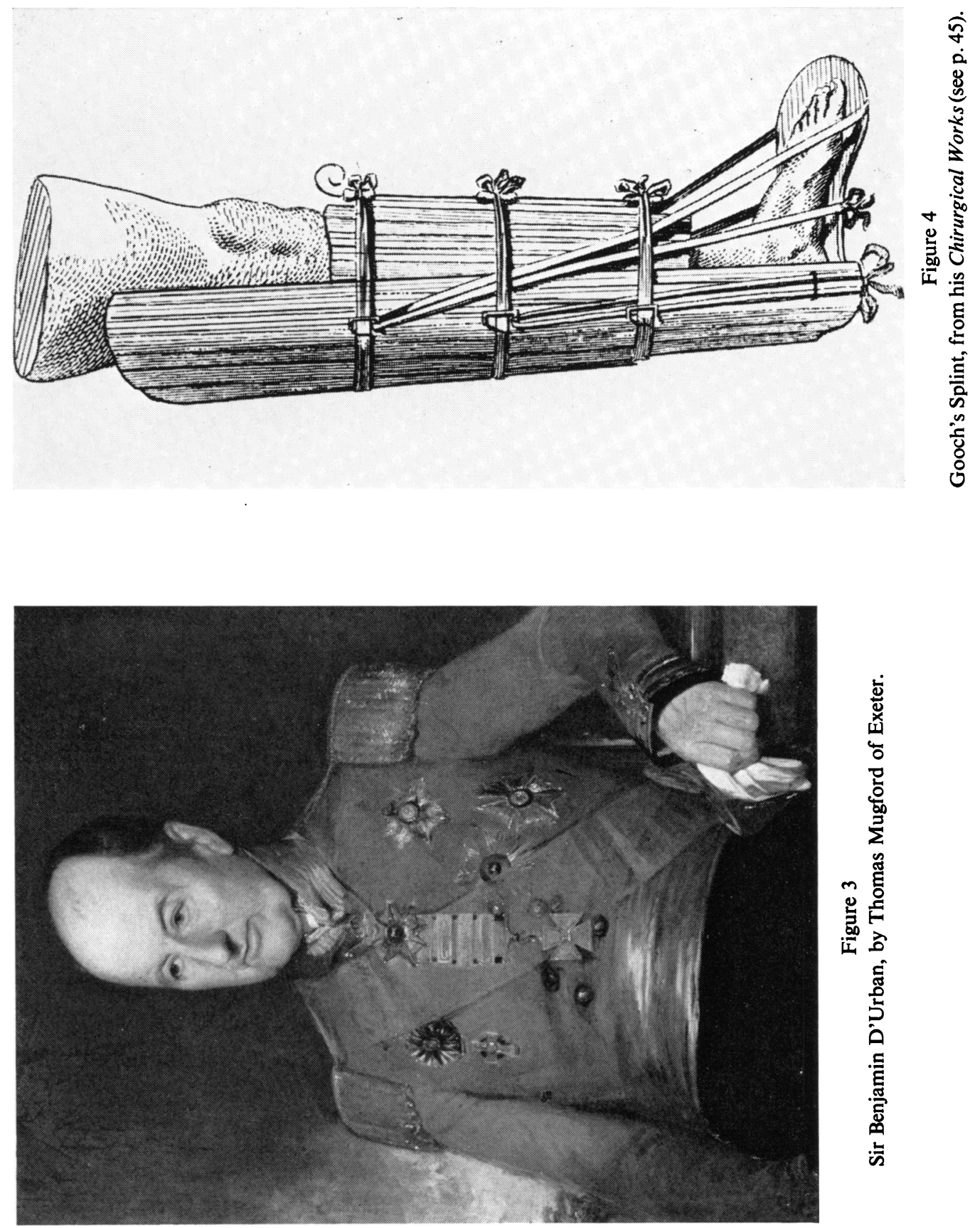

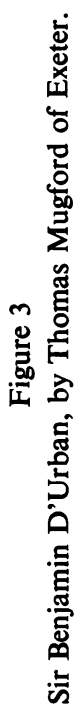




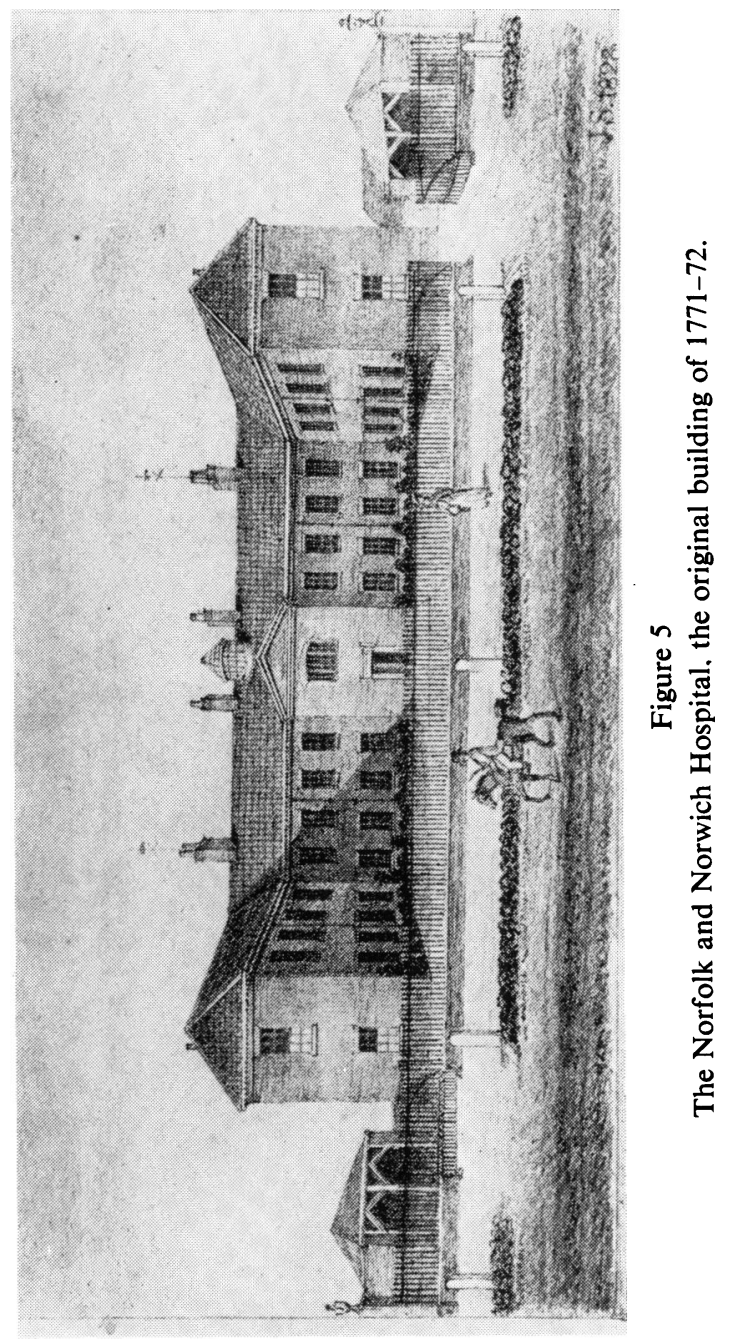




\section{Benjamin Gooch, Eighteenth-Century Norfolk Surgeon}

estate that he purchased in Norfolk, where he was a magistrate and much concerned with other local charitable works in addition to founding two hospitals. A son, Robert Fellowes (1742-1829), a Member of Parliament for Norwich, maintained his father's interest in hospital work and succeeded him as treasurer of the Norfolk and Norwich Hospital. A grandson, the Reverend Robert Fellowes (1770-1847) continued the family tradition of a concern for hospital work by endowing prizes for the "two students who shall most distinguish themselves by reports and observations on the medical cases in the North London Hospital'. ${ }^{28}$ This gift was made in 1837, the year in which the North London was re-named University College Hospital and annual awards of Fellowes Gold and Silver Medals are still made by University College Hospital Medical School. Direct descendants of William Fellowes have lived at Shotesham Park for two centuries and several of them have had close associations with the work of the Norfolk and Norwich Hospital.

The year in which William Fellowes 'erected' Shotesham Infirmary is not known. He purchased the Shotesham estates in 1731 and the first dated reference to the hospital's use by Gooch is 1754 so it must have been between these years. Describing another case in 1756 Gooch wrote that this was admitted 'into Mr. Fellowes Infirmary at Shotesham which I had the use of then and afterwards, as long as my health permitted'. Shotesham Infirmary was an early cottage or village hospital and when it was claimed that Cranleigh Village Hospital, Surrey, founded in 1859, was the oldest cottage hospital in England, 20,30 this was disputed by Norfolk. The cottage style building which Fellowes built still stands and has been converted to a private residence; it contained two rooms that could have taken ten to twelve patients and local tradition attributes the use of adjacent buildings to accommodation for the nursing staff, mentally disturbed patients and other purposes. Though called Shotesham Infirmary it was not a workhouse for Fellowes established a separate workhouse, or house of industry, for Shotesham and again this building survives and is in use as a private residence. No reference can be traced to the use of the Infirmary in the nineteenth century or in the last years of the eighteenth century; it probably fell into disuse after the Norfolk and Norwich Hospital was opened in 1772. The difficulty of providing an exact definition of a cottage or village hospital has been discussed by McConaghey ${ }^{31}$ but Shotesham Infirmary can justly claim to have been one and Norfolk has claimed that it was the first cottage hospital to be built in England. There may have been other village hospitals in existence at the time so it is difficult to know for certain if this is so, but Shotesham Infirmary must certainly have been among the earliest of them. Should Norfolk's claim be valid, Cranleigh's distinction of having the oldest cottage or village hospital in England that still remains in use is not disputed.

William Fellowes is rightly honoured as the founder of the Norfolk and Norwich Hospital, whose foundation stone he laid in March 1771, but he brought to fruition a scheme first initiated by Thomas Hayter, Bishop of Norwich from 1749-1761, ${ }^{32}$ and assisted by Gooch with his professional expertise. With a view to founding a general hospital in Norwich, Hayter wrote to Gooch when he was in London in 1758 and the two had several meetings to discuss the project. 'At his Lordship's request I [Gooch] visited all the hospitals in London with the greatest attention.' 


\section{A. Batty Shaw}

Plans for a hospital were drawn up based on the latest London experience together with a scheme for its administration. But in 1761 Hayter was translated to London, died a few months later, and the plan for a hospital in Norwich 'lay dormant'. In 1767 Gooch wrote that 'I have good reason to believe that, had he [the Bishop] lived and continued Bishop of Norwich, such a beneficient establishment [the hospital] would have been completed ere now ... and nothing seems wanting even now to accomplish it but to have a subscription properly opened'. It was the need for an organized subscription fund that William Fellowes, Gooch's patron at Shotesham met. He called an open meeting at the Guildhall, Norwich, in August 1770 to discuss the project and the outcome was the appointment of a committee of wealthy and influential Norfolk gentry, the opening of a subscription fund and the purchase of a site for the hospital. Thereafter the scheme never faltered (Fig. 5). Gooch gave continued advice and assistance to William Fellowes and became the only medical member of a sub-committee of six men, including Fellowes and the Reverend Samuel Cooper, father of Sir Astley, appointed to draw up the first rules and orders for the conduct and government of the hospital. In October 1771 the first medical members of the staff were appointed and in their selection Gooch was the main assessor.

Gooch had both a distinguished surgical career and played a prominent role in the foundation of the Norfolk and Norwich Hospital, where a copy of his portrait in Figure 1 hangs in its medical staff room. Gooch's name is, and will be, commemorated in two other ways at the hospital. In 1965 when an annual prize for junior medical staff in the Norfolk and Norwich Hospital area was introduced, it was named the Benjamin Gooch prize, thereby commemorating Gooch's interest in young medical men. These he exhorted 'by beginning early to make observations, taking minutes of extraordinary occurrences in practice and making them occasionally the subjects of reflection [you] will receive great advantages'. Gooch also had the prescience to see a hospital as a place for medical education as well as for treatment of the sick. When he wrote as follows, Gooch was mainly concerned with the needs of the pupils who attended the practice of the county hospitals during his day but his remarks have a wider and contemporary significance, 'To those gentlemen concerned in the management of hospitals ... . as well the governors as the physicians and surgeons', he submitted, 'the proposition that it might be beneficial ... to have a skeleton and a few other practical, anatomical preparations to have recourse to occasionally, and a suitable collection of practical books in Latin, French and English, kept in a room appropriated to this purpose . . . . The expense to the hospital fund would be very trifling compared with the benefit that I humbly conceive would accrue with it.' It is therefore proposed to name the main lecture hall of the hospital's teaching centre, to be completed in 1973, the Benjamin Gooch Hall. The hall will be adjacent to the only part of the hospital built in Gooch's day that escaped demolition when the hospital was rebuilt in 1879-1883 and that will again escape destruction in the second major rebuilding scheme currently in progress after another hundred years. Benjamin Gooch was interested in the work of young medical men and the educational role of a hospital but his motto for the main object of a hospital was patet omnibus. This is an appropriate motto for his hospital, the Norfolk and Norwich Hospital, in its two hundredth anniversary year. 


\section{Benjamin Gooch, Eighteenth-Century Norfolk Surgeon}

\section{ACKNOWLEDGEMENTS}

The main material for this article has been obtained from Benjamin Gooch's Chirurgical Works. Additional biographical material has been made available by one of his direct descendants, Mrs. A. D'Urban Smith of Sidmouth; to her and her husband I express my grateful acknowledgement of this material and for permission to reproduce the portraits in their possession of Benjamin Gooch and Lieutenant-General Sir Benjamin D'Urban (Figs. 1 and 3); the photographs of the portraits are by Hayes Studios of Sidmouth. I am grateful to the Marquess of Bath for his kind permission to reproduce the portrait of Lord Thurlow in his possession at Longleat and the Courtauld Institute of Art for the photograph of it (Fig. 2). I owe thanks to Miss J. Kennedy of the Norfolk and Norwich Record Office for enabling me to study the will of the Reverend Benjamin Gooch (Norwich Consistory Court No. 281, 1728) and to Professor E. B. Adams of the Faculty of Medicine, University of Natal, for help in tracing places in South Africa named after Sir Benjamin D'Urban. To the incumbents and others who live today in the Norfolk villages where Gooch spent his life, I express my gratitude for all their help with my searches; their names are too numerous to list. A search of the registers at All Saints Church, Ashwellthorpe and of other possible sources failed to reveal the date of birth of Benjamin Gooch. The house in which he lived at Shotesham is now named 'Dukeshead' and the house of industry 'Henstead Cottage'. On the basis of well-established local tradition the building that was once Shotesham Infirmary, since modernised and enlarged, has been identified as 'Oak Lodge', Hawes Green, Shotesham St. Mary. Finally I express my indebtedness to the following librarians for their services: L. M. Payne, Royal College of Physicians of London, E. Cornelius, Royal College of Surgeons of England, A. T. Picton, University College Hospital Medical School, P. Hepworth and F. D. Sayer, Central Public Library, Norwich, Mrs. F. V. Batchelor, Norfolk and Norwich Hospital Library and Mrs. J. C. Langner, Killie Campbell Africana Library, University of Natal.

\section{REFERENCES}

1. Gooch, B., in Dictionary of National Biography, 22, 107.

2. BAIlEY, H. and Bishop, W. J., Notable Names in Medicine and Surgery, London, H. K. Lewis, 1944, pp. 22-3.

3. Venn, J., Biographical History of Gonville and Caius College, Cambridge, 1349-1897, 3 vols., Cambridge University Press, vol. 1, p. 480.

4. Batty Shaw, A., Guy's Hosp. Rep., 1968, 117, 169-92.

5. ThuRLow, E., First Baron Thurlow, in Dictionary of National Biography, 56, 344-49.

6. Camprell, J. Lord, The Lives of the Lord Chancellors of the Great Seal of England, 7 vols., London, J. Murray, 1846, vol. 5., pp. 453-678.

7. Wall, C., The History of the Surgeons' Company, 1745-1800, London, Hutchinson, 1937, pp. 189-94, 214.

8. MoRgan, SIR C. N., Annals of the Royal College of Surgeons of England, 1968, 42, 34.

9. A collection of pamphlets concerning the evolution of the College out of the Company of Surgeons. $1797-1800$ (R.C.S. Library) Tract No. 6 A Dressing for $L^{* *} d T^{* *} r^{* *} w$, by a Surgeon, London, 1797, C. Wall (op. cit. pp. 207-8) attributed the pamphlet to John Birch.

10. D'URBan, SIR B., in Dictionary of National Biography, 16, 249-50.

11. Malherbe, J., Port Natal, Cape Town, Howard Timmins, 1965, p. 19.

12. Gooch, B., Cases and Practical Remarks in Surgery, London, D. Wilson \& T. Durham, 1758.

13. Sharp, S., A Treatise on the Operations of Surgery, London, 1839.

14. WARNER, J., Cases in Surgery, London, J. and R. Tonson \& S. Draper, 1754.

15. HeIsTER, L., A General System of Surgery, Eng. trans., London, 1839.

16. Gooch, B., 2 vols., Vol. 1, A Practical Treatise on Wounds and other Chirurgical Subjects to which is prefixed a short Historical Account of the Rise and Progress of Surgery and Anatomy addressed to Young Surgeons; Vol. 2, Cases and Practical Remarks in Surgery, Norwich, W. Chase, 1767.

17. Idem., Medical and Chirurgical Observations, as an appendix to a former publication, London, G. Robinson; Norwich, R. Beatniffe, 1773.

18. Idem., The Chirurgical Works of Benjamin Gooch, Surgeon; a New Edition with his last

Corrections and Additions, 3 vols., London, J. Johnson, 1792.

19. Batty Shaw, A., Med. Hist., 1970, 14, 221-59. 


\section{A. Batty Shaw}

20. Willams, C., Lancet, 1885 , ii, 847-48.

21. Gooch, B., Phil. Trans. R. Soc. Lond., 1775, 65, 378-83.

22. Ibid., 373-77.

23. WARnER, J., Phil. Trans. $R$. Soc. Lond., 1769, 59, $281-83$.

24. Gould, G. M. and PYLe, W. L., Anomalies and Curiosities of Medicine, London, Redman, 1898, pp. 832-34.

25. WARNER, J., op. cit., 4th ed., 1784, p. 91.

26. Idem., in Dictionary of National Biography, 59, 396-97.

27. Batty Shaw, A., Norfolk Archaeology, 1971, 35, Pt. 2, 183-91.

28. Fellowes, Rev. R., in Dictionary of National Biography, 18, 300-1.

29. Swete, H., Handybook of Cottage Hospitals, London, Hamilton \& Adams, 1870.

30. Burdett, H. C., The Cottage Hospital, London, J. \& A. Churchill, 1877.

31. McConaghey, R. M. S., 'The evolution of the cottage hospital', Med. Hist., 1967, 11, $128-40$.

32. HAYTER, T., in Dictionary of National Biography, 25, 305-7. 